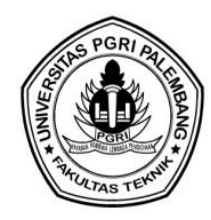

\title{
ANALISA PENGARUH SERBUK KACA DAN ABU TERBANG SEBAGAI BAHAN PENGGANTI ALTERNATIF TERHADAP KUAT TEKAN BETON
}

\author{
Amiwarti $^{1^{*}}$, Mahipal ${ }^{2}$ \\ ${ }^{12}$ Prodi Teknik Sipil Fakultas Teknik Universitas PGRI Palembang \\ *Corresponding Author, Email : amiwartiishak@gmail.com
}

\begin{abstract}
ABSTRAK
Penelitian ini bertujuan untuk mengetahui nilai kuat tekan beton pada masing-masing kandungan prosentase campuran serbuk kaca dan abu terbang sebagai pengganti terhadap sebagian dari berat agregat halus dan semen dalam adukan beton serta mengetahui variasi perbandingannya. Kandungan prosentase campuran serbuk kaca terhadap sebagian dari berat agregat halus adalah 5\%, 10\%, 15\%, 20\% dan 25\% sedangkan abu terbang sebesar 5\% sebagian dari berat semen. Pengujian kuat tekan dilakukan pada saat beton sudah mencapai umur 3, 14 dan 28 hari dari tanggal pengecoran dengan menggunakan benda uji selinder ukuran $15 \times 30 \mathrm{~cm}$ sebanyak 54 sample. Dimana masing-masing kandungan prosentase campuran dibuat 9 sampel dan setiap umur beton dibuat 3 sampel. Rancangan proporsi campuran beton dengan metode SNI-03-2834-2000 tercapai, karena kuat tekan rata-rata beton normal yang didapat dari hasil kajian laboratorium pada target umur 28 hari mencapai hasil yang direncanakan yaitu sebesar Fc' 25,57 MPa dan mengalami peningkatan kekuatan sebesar 2,28\% terhadap kuat tekan beton rencana yaitu Fc' 25,00 MPa. Dari hasil pengujian yang telah dilakukan bahwa pada penambahan campuran volume fraksi serbuk kaca dan abu terbang sebesar (Fc'-SK 25\% + AT 5\%) pada umur 3, 14 dan 28 hari nilai kekuatan hancur tekannya lebih tinggi dibandingkan dengan atau tanpa penambahan campuran volume fraksi serbuk kaca dan abu terbang sebesar (Fc'-SK 5\%, 10\%, 15\%, 20\% + AT 5\%). Dari hasil penelitian analisa pengaruh serbuk kaca dan abu terbang sebagai bahan pengganti alternatif terhadap kuat tekan beton diperoleh komposisi campuran yang optimal yaitu (FC'-SK 15\% + AT 5\%) karena pada umur 28 hari nilai kuat tekan beton rata-ratanya sebesar 26,99 MPa dengan pencapaian peningkatan kekuatan beton normal sebesar $5,55 \%$.
\end{abstract}

Kata kunci : Kuat Tekan, Subtitusi, Fly Ash, Serbuk Kaca.

\section{PENDAHULUAN}

Beton merupakan fungsi dari bahan penyusunnya yang terdiri dari bahan semen hidrolik (Portland cement), agregat kasar, agregat halus, air dan bahan tambah (admixture atau additive) yang membentuk masa padat (Tri Mulyono, 2003). Beton disusun dari agrgegat halus dan agregat kasar Agregat halus digunakan biasanya pasir alam sedangkan agregat kasar yang dipakai biasanya berupa batu alam maupun batuan yang dihasilkan oleh industri pemecah batu. Berkembangnya teknologi beton di zaman sekarang ini, semakin banyak pula inovasi untuk meningkatkan mutu beton serta penyesuaian pekerjaan dilapangan. Salah satu inovasi tersebut adalah dengan memasukan sebagian bahan pengganti (subtitusi) kedalam campuran penyusun beton. Bahan pengganti merupakan bahan yang digantikan pada saat atau selama pencampuran berlangsung. Fungsi dari bahan pengganti campuran beton adalah untuk memodifikasi sifat-sifat dari beton dan karakteristik dari beton misalnya untuk meningkatkan kemudahan pengerjaan (workability), durability, penghematan biaya dan waktu pengerasan beton (Agus Setiawan, 2016). 
Adapun rumusan masalah dari penelitian ini adalah Bagaimana pengaruh campuran serbuk kaca sebagai bahan pengganti dari sebagian berat agregat halus dan abu terbang sebagai bahan pengganti sebagian berat semen terhadap nilai kuat tekan beton. Dari rumusan masalah diatas, maka penelitian ini bertujuan mengetahui nilai kuat tekan beton pada masing-masing kandukan prosentase campuran serbuk kaca dan abu terbang sebagai bahan pengganti terhadap sebagian dari berat agregat halus dan semen dalam adukan beton serta mengetahui variasi perbandingan kandungan prosentase campuran serbuk kaca dan abu terbang yang dipakai. Sedangkan manfaat penelitianyang didapat adalah untuk $\mathrm{t}$ meningkatkan nilai tambah dan nilai guna dari limbah bekas industri maupun rumah tangga serta menambah wawasan mengenai studi tentang bahan bangunan dan juga mengurangi pencemaran dalam rangka menunjang usaha peningkatan kualitas lingkungan.

\section{TINJAUAN PUSTAKA}

Menurut Teknologi Beton 2003, Tri Mulyono (SNI-03-2847-2002) adalah campuran antara semen portland atau semen hidrolis yang lain, agregat halus, agregat kasar dan air dengan atau tanpa bahan tambahan (additive) yang berfungsi untuk merubah sifat-sifat tertentu dari beton tersebut jika diperlukan. Beton mempunyai banyak faktor diantaranya ialah nilai banding campuran, mutu bahan penyusunnya, metode pelaksanaan pengecoran, pelaksanaan finishing, temperatur dan kondisi perawatan pengerasan. Beton banyak dipakai oleh para ahli struktur untuk digunakan sebagai material bangunan, karena beberapa keunggulannya. Dalam keadaan mengeras, beton bagaikan batu karang dengan kekuatan tinggi. Selain tahan terhadap serangan api, beton juga tahan terhadap korosi (Tri Mulyono, 2003).

\section{Material Pembentuk Beton}

Dalam memahami dan mempelajari seluruh perilaku elemen gabungan diperlukan pengetahuan tentang karakteristik masing-masing komponen. Beton dihasilkan dari sekumpulan interaksi mekanis dan kimiawi sejumlah material pembentuknya. Dengan cara demikian seorang perencana dan ahli bahan dapat mengembangkan pemilihan material yang layak dan komposisinya sehingga diperoleh beton yang efisien, memenuhi kekuatan yang disyaratkan oleh perencana dan memenuhi persyaratan serviceability (Edgar G. Nawy, 2010).

\section{Semen}

Semen yang merupakan salah satu bahan dasar pembuatan beton tergolong ke dalam jenis semen hidrolis. Jenis semen yang banyak digunakan hingga saat ini adalah merupakan semen portland yang dipatenkan di Inggris pada tahun 1824 atas nama Joseph Aspdin. Semen portland adalah material berbentuk bubuk bernama abu-abu dan banyak mengandung kalsium dan aluminium silika (Agus Setiawan, 2016).

Semen yang digunakan dalam campuran meliputi portland cement atau campuran semen hidrolik. Semen portland adalah bahan konstruksi yang paling banyak digunakan dalam pekerjaan beton. Menurut ASTM C-150-1985, semen portland didefinisikan sebagai semen hidrolik yang dihasilkan dengan menggiling klinker yang terdiri dari kalsium-silikat-hidrolik yang umumnya mengandung satu sama dengan bahan utamanya. 
Seperti gipsum, jika bubuk-bubuk tersebut dicampur air dalam beberapa waktu dapat menjadi keras.

Adanya perbedaan kebutuhan akan sifat semen maka menyebabkan semen dibagi menjadi beberapa tipe menurut SNI-15-3550-2004 Ordinar Portland Cement (OPC), yaitu:

Tipe I - Semen Portland Normal

Tipe II — Semen Portland Moderat

Tipe III - Semen Portland untuk Kekuatan Awal yang Tinggi

Tipe IV — Semen Portland Dengan Panas Hidrasi Rendah

Tipe V — Semen Portland Tahan Sulfat

\section{Agregat}

Berdasarkan standar SK SNI-5-04-1989-E, agregat yaitu bahan baku beton yang berupa pasir, kerikil atau batu pecah dan beberapa kombinasi dari bahan itu. Agregat merupakan komponen beton yang paling berperan dalam menentukan besarannya (Edwar G. Nawy, 2010).

\section{Air}

Dalam pembuatan beton air digunakan sebagai pereaksi semen menjadi pasta sehingga campuran beton tersebut bisa dikerjakan. Syarat air menurut (SK SNI 03-28472002), air yang digunakan untuk campuran beton harus bersih, tidak mengandung minyak, asam, alkali, garam, zat organik atau bahan lainnya yang bersifat merusak beton atau tulangan. Pada umumnya air yang digunakan dalam pembuatan beton yaitu air tawar yang dapat diminum (Tri Mulyono, 2003).

\section{Bahan Pengganti}

Penggunaan dan pemanfaatan limbah padat sebagai bahan pengganti (subtitusi) terhadap sebagian dari berat agregat halus maupun semen yang dibutuhkan dalam campuran adukan beton seperti pemakaian serbuk kaca (glass powder) dan abu terbang (fly ash). Admixture adalah bahan-bahan yang ditambahkan ke dalam campuran beton pada saat atau selama pencampuran berlangsung. Fungsi dari bahan-bahan ini ialah untuk mengubah sifat-sifat dan karakteristik dari beton agar menjadi lebih cocok untuk pekerjaan tertentu, mempercepat pengerasan dan penghematan biaya (Tri Mulyono, 2003).

\section{Serbuk Kaca}

Bahan limbah botol kaca sebagai bahan pengganti pada agregat halus. Terdiri dari gradasi yang memberikan kuat tekan mortar yang diperlukan, sehingga pada suatu uji bahan lebih banyak ditekankan pada gradasi agregat halus dan mengikuti ASTM C-33077-A dan ASTM C-330-68-T.

Penelitian telah menunjukkan bahwa kaca dapat secara efektif digunakan dalam beton baik sebagai agregat atau sebagai pozzolan. Limbah dari botol kaca ketika dilakukan penumbukan dan disaring yang tertahan di No.8 $(2,36 \mathrm{~mm})$ kemudian hasilnya menjadi serbuk yang halus. Oleh karena itu serbuk kaca dapat menggantikan sebagian dari berat 
agregat halus dan diharapkan dapat berkontribusi terhadap kekuatan beton dalam daya ikat material.

\begin{abstract}
Abu Terbang
Menurut (SNI-03-6414-2002) mendefinisikan, abu terbang merupakan limbah padat hasil dari proses pembakaran batu bara pada tungku pembangkit listrik tenaga uap yang terbentuk halus, bundar dan bersifat fozalanik kemudian terbawa keluar oleh sisa-sisa pembakaran serta ditangkap dengan menggunakan elektrostatic precipitator. Abu terbang merupakan residu mineral dalam butiran halus yang dihasilkan dari pembakaran batu bara. Abu terbang terdiri dari bahan inorganik yang terdapat dalam batu bara yang telah mengalami fusi selama pembakarannya. Partikel-partikel abu terbang umumnya berbentuk bulat, biasanya berukuran silt $(0,074-0,005 \mathrm{~mm})$ yang terdiri dari silikon dioksida ( $\mathrm{SiO} 2)$, aluminium oksida (Al2O3) dan besi oksida (Fe2O3).
\end{abstract}

\title{
Kuat Beton Terhadap Gaya Tekan
}

Metode pengujian kuat tekan beton menurut SNI-03-1974-1990, yaitu perilaku beton dalam menahan gaya yang bekerja tergantung pada hubungan regangan-tegangan yang terjadi di dalam beton dan juga jenis tegangan yang dapat ditahan. Karena sifat bahan beton yang hanya mempunyai nilai kuat tarik relatif rendah, maka pada umumnya hanya diperhitungkan bekerja dengan baik di daerah tekan pada penampangnya dan hubungan regangan-tegangan yang timbul karena pengaruh gaya tekan tersebut digunakan sebagai dasar pertimbangan.

Kekuatan tekan merupakan salah satu kinerja utama beton. Kekuatan tekan adalah kemampuan beton untuk menerima gaya tekan persatuan luas. Penentuan kekuatan tekan dapat dilakukan dengan menggunakan alat uji tekan dan benda uji berbentuk silinder dengan prosedur uji ASTM C-39 atau dengan kubus dengan prosedur BS-1881 pada umur 28 hari (Tri Mulyono, 2003).

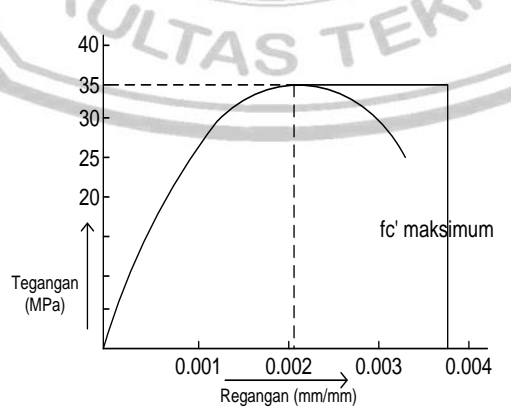

Gambar 1. Grafik Hubungan Tegangan dan Regangan BetonKarena Gaya Tekan

Formula yang dipakai untuk menghitung kuat tekan baik bentuk silinder maupun kubus yaitu:

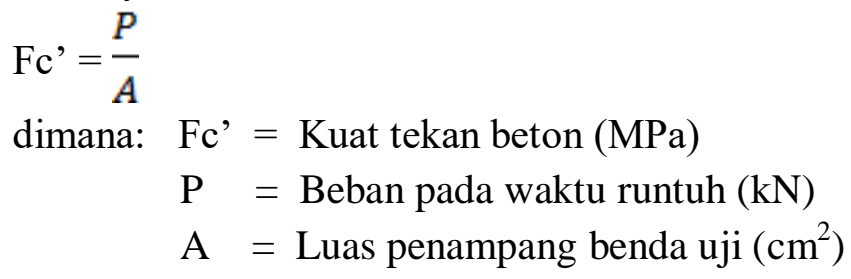


Dengan demikian, penting untuk disadari adanya perbedaan hasil pengujian dari kedua bentuk benda uji sehubungan dengan gambaran kekuatan beton yang ingin diketahui, merupakan hal yang sulit untuk dapat merumuskan secara tepat hubungan nilai kekuatan yang dihasilkan oleh kedua bentuk untuk berbagai kondisi beton metode pengujiannya.

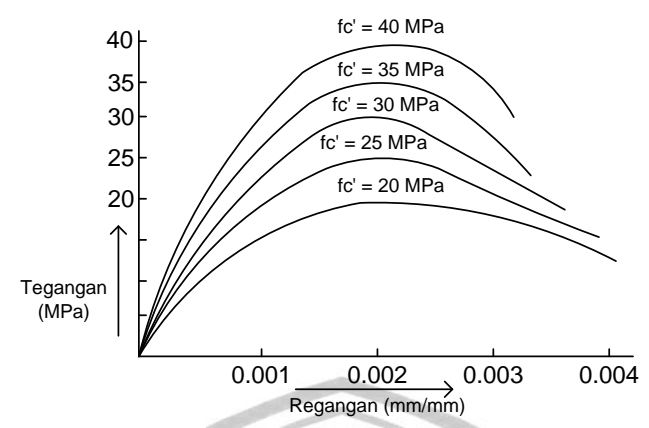

Gambar 2. Grafik Kuat Tekan Benda Uji Beton Berumur 28 Hari

\section{METODOLOGI PENELITIAN}

Pada analisis data adalah tahapan terakhir dari suatu penelitian. Baik-buruk, benarsalah bahkan sampai pada dipercaya maupun tidak/dipercaya tergantung pada analisis data. Sebaik apapun data yang diperoleh akan tetapi dalam pengolahan data tidak benar maka hasilnya pun akan salah, analisis data yang dilakukan tergantung pada jenis penelitiannya, apakah kualitatif atau kuantitatif. Tentunya kalau kuantitatif akan bersifat tanpa ada analisis hitungan statistik dan jika kuantitatif akan ada hitungan analisis statistik, keduanya ini juga akan mempengaruhi cara menganalisis data yang ada. Biasanya untuk jenis penelitian yang kualitatif ini mengarah pada penelitian yang diskreptif/historis, sedangkan untuk kuantitatif termasuk penelitian yang eksperimen.

Penelitian ini dilakukan untuk mengetahui pengaruh pemanfaatan bahan limbah padat yaitu botol kaca sebagai bahan pengganti terhadap sebagian dari berat agregat halus dan abu terbang sebagai bahan pengganti sebagian dari berat semen dengan membandingkan hasil nilai kuat tekan beton normal. Untuk pembuatan benda uji menggunakan cetakan berbentuk selinder ukuran $15 \times 30 \mathrm{~cm}$. Pengujian kuat tekan beton dilakukan pada saat sudah mencapai umur 3, 14 dan 28 hari dari tanggal pengecoran dengan total benda uji sebanyak 54 sampel, dimana masing-masing campuran bahan pengganti kandungan prosentase beton sebanyak 9 sampel dan setiap masing-masing umur beton diuji sebanyak 3 sampel.

\section{ANALISA DAN PEMBAHASAN}

\section{Pemeriksaan Propertis Agregat}

Sebelum mendesain atau membuat rancangan proporsi campuran adukan beton (concrete mix design) menggunakan metode SNI-03-2834-2000 dalam penelitian ini direncanakan yaitu mutu beton Fc 25,00 MPa maka terlebih dahulu dilakukan pemeriksaan agregat, baik agregat halus maupun agregat kasar guna untuk mengetahui 
nilai properties dari agregat tersebut. Resume hasil pemeriksaan properties agregat dapat dilihat pada tabel dibawah ini.

Tabel 1. Resume Hasil Pemeriksaan Properties Agregat

\begin{tabular}{|c|c|c|c|c|}
\hline \multirow[b]{2}{*}{ No } & \multirow{2}{*}{\multicolumn{2}{|c|}{ Pemeriksaan }} & \multicolumn{2}{|c|}{ Agregat } \\
\hline & & & $\begin{array}{c}\text { Pasir } \\
\text { Ex. Tanjung Raja }\end{array}$ & $\begin{array}{c}\text { Batu Pecah 2/3 } \\
\text { Ex. Lahat }\end{array}$ \\
\hline 1 & \multicolumn{2}{|c|}{ Kadar Organik (No.) } & 2 & - \\
\hline 2 & \multicolumn{2}{|c|}{ Kadar Lumpur (\%) } & 2,672 & - \\
\hline \multirow{2}{*}{3} & \multirow{2}{*}{$\begin{array}{l}\text { Berat } \\
\text { Volume }\end{array}$} & Padat (kg/liter) & 1,476 & 1,594 \\
\hline & & Gembur (kg/liter) & 1,331 & 1,454 \\
\hline 4 & \multicolumn{2}{|c|}{ Modulus Kehalusan (FM) } & 2,588 & 3,960 \\
\hline 5 & \multicolumn{2}{|c|}{ Kadar Air $(\%)$} & 5,548 & 1,873 \\
\hline \multirow{4}{*}{6} & \multicolumn{2}{|c|}{ Bulk Specifik Gravity (Kering) } & 2,286 & 2,526 \\
\hline & \multicolumn{2}{|c|}{ Apparent Specific Gravity } & 2,380 & 2,618 \\
\hline & \multicolumn{2}{|c|}{ Bulk Specific Gravity (SSD) } & 2,326 & 2,560 \\
\hline & \multicolumn{2}{|c|}{ Persentase Absorsi Air (\%) } & 21,735 & 1,376 \\
\hline
\end{tabular}

a) Jumlah air yang terdapat dalam agregat halus dan agregat kasar adalah:

- Pasir $=(5,548-1,735) \times 609,77 / 100=23,25 \mathrm{~kg} / \mathrm{m}^{3}$

- Batu Pecah $2 / 3=(1,873-1,376) \times 1038,27 / 100=5,16 \mathrm{~kg} / \mathrm{m}^{3}$

b) Jadi perhitungan proporsi campurannya adalah:

- Semen

$=401,96 \mathrm{~kg} / \mathrm{m}^{3}$

- Air

$$
\begin{aligned}
= & 205-\{(5,548-1,735) / 100 \times 609,77\} \\
& \{(1,873-1,376) / 100 \times 1038,27\}
\end{aligned}
$$$$
=205-(23,25)-(5,16)
$$

$=176,59 \mathrm{ltr} / \mathrm{m}^{3}$

- Pasir

$$
\begin{aligned}
& =609,77+\{(5,548-1,735) / 100\} \times 609,77 \\
& =633,02 \mathrm{~kg} / \mathrm{m}^{3}
\end{aligned}
$$

- Batu Pecah $2 / 3=1038+\{(1,873-1,376) / 100\} \times 1038,27$

$$
=1043,43 \mathrm{~kg} / \mathrm{m}^{3}
$$

Tabel 2. Komposisi Kebutuhan Material Untuk 54 Sample Benda Uji Selinder Dengan Kapasitas Mesin Pengaduk = 120 Liter $\left(0,12 \mathrm{M}^{3}\right)$

\begin{tabular}{|l|c|c|c|c|c|c|}
\hline \multicolumn{1}{|c|}{ Proporsi Campuran } & $\begin{array}{c}\text { Semen } \\
(\mathrm{kg})\end{array}$ & $\begin{array}{c}\text { Air } \\
(\mathrm{kg} / \mathrm{ltr})\end{array}$ & $\begin{array}{c}\text { Pasir } \\
(\mathrm{kg})\end{array}$ & $\begin{array}{c}\text { Batu } \\
\text { Pecah 2/3 } \\
(\mathrm{kg})\end{array}$ & $\begin{array}{c}\text { Serbuk } \\
\text { Kaca } \\
(\mathrm{kg})\end{array}$ & $\begin{array}{c}\text { Abu } \\
\text { Terbang } \\
(\mathrm{kg})\end{array}$ \\
\hline Mix I Fc'-SK 0\% + AT 0\% & 22,05 & 9,72 & 34,74 & 57,24 & - & - \\
\hline Mix II Fc'-SK 5\% + AT 5\% & 20,95 & 9,72 & 33,00 & 57,24 & 1,34 & 1,10 \\
\hline Mix III Fc'-SK 10\% + AT 5\% & 20,95 & 9,72 & 31,27 & 57,24 & 3,47 & 1,10 \\
\hline Mix IV Fc'-SK 15\% + AT 5\% & 20,95 & 9,72 & 29,53 & 57,24 & 5,21 & 1,10 \\
\hline Mix V Fc'-SK 15\% + AT 5\% & 20,95 & 9,72 & 27,79 & 57,24 & 6,95 & 1,10 \\
\hline Mix VI Fc'-SK 15\% + AT 5\% & 20,95 & 9,72 & 26,05 & 57,24 & 8,69 & 1,10 \\
\hline Total & 126,80 & 58,32 & 182,38 & 343,44 & 26,06 & 5,50 \\
\hline
\end{tabular}


Keterangan ;

a) SK : Prosentase kandungan serbuk kaca (glass powder) sebagai bahan pengganti terhadap sebagian dari jumlah berat pasir dalam campuran adukan beton

b) AT : Prosentase kandungan abu terbang (fly ash) sebagai bahan pengganti terhadap sebagian dari jumlah berat semen dalam campuran adukan beton

\section{Pengujian Kuat Tekan Beton}

Setelah dilakukan pencetakan, pengukuran nilai slump dan perawatan benda uji selinder ukuran $15 \times 30 \mathrm{~cm}$ selanjutnya dilakukan pengujian kuat tekan beton. Pengujian kuat tekan beton dilakukan sudah mencapai umur 3,14 dan 28 hari dari tanggal pengecoran. Total benda uji 54 sampel yang terdiri dari VI (enam) komposisi prosentase volume fraksi campuran yang tercantum pada tabel 3.4, dimana masing-masing volume fraksi campuran serbuk kaca sebagai subtitusi pasir dan abu terbang (fly ash) sebagai subtitusi semen dibuat 9 sampel atau 3 sampel setiap umur beton. Perhitungan lengkapnya dapat dilihat pada tabel dan gambar grafik hasil data pengelolahan kuat tekan beton dibawah ini:

Tabel 3. Pengolahan Data Hasil Pengujian Kuat Tekan Beton Normal (Fc'-SK 0\% + AT 0\%) Terhadap Fc’25,00 MPa Menggunakan Benda Uji Selinder Ukuran 15x30 $\mathrm{Cm}$.

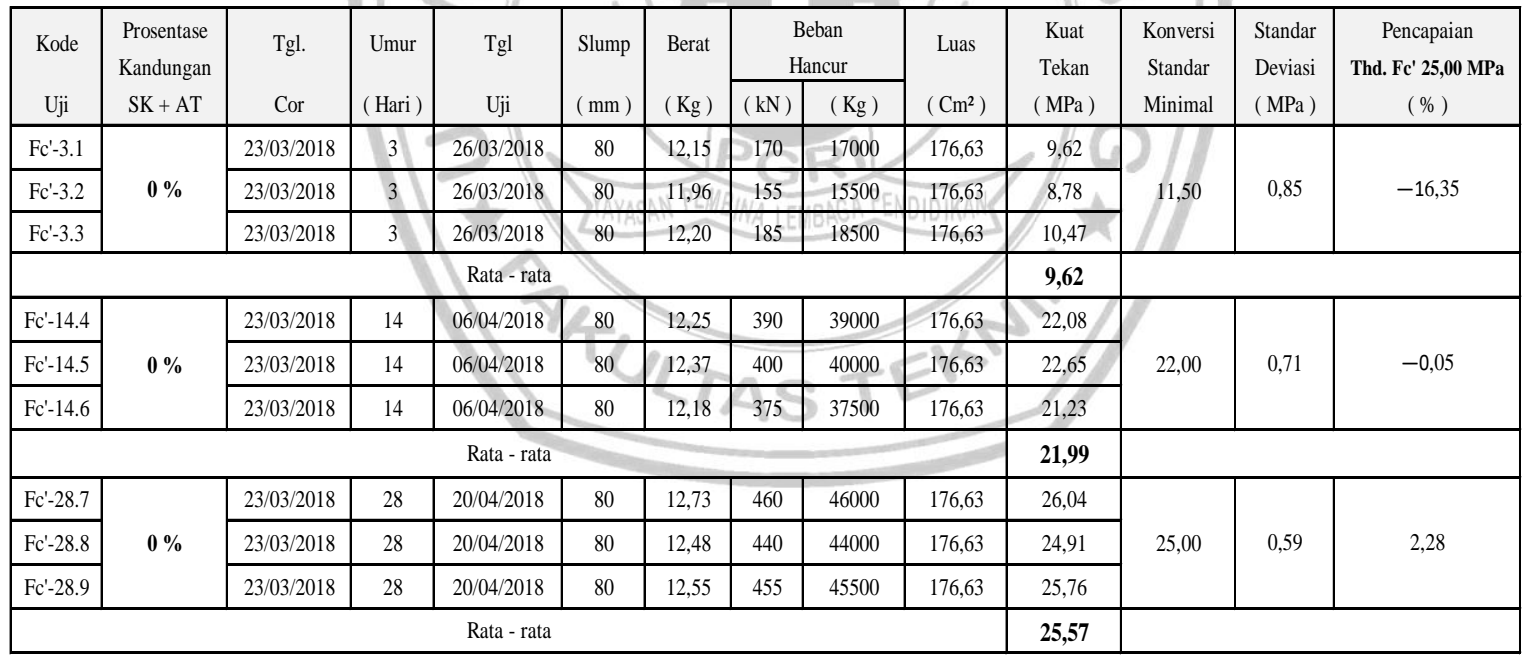

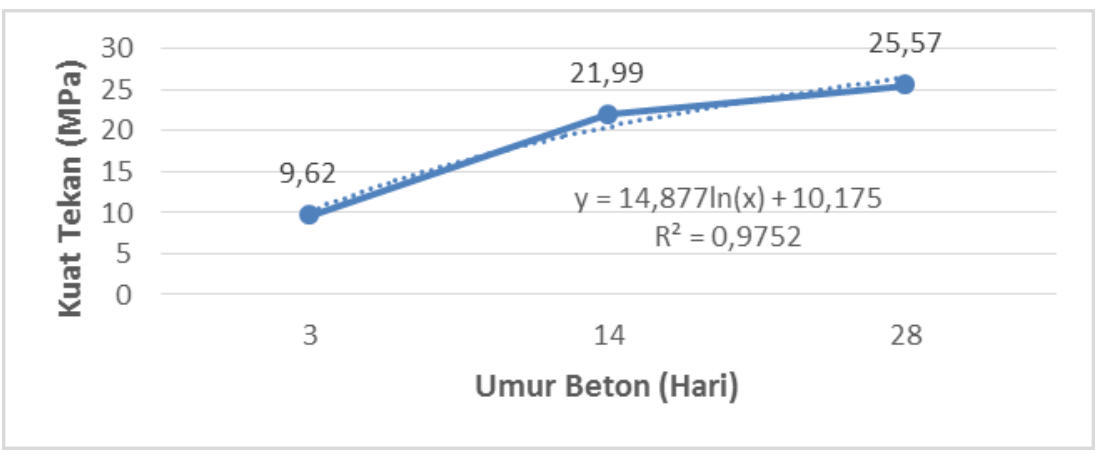

Gambar 3. Grafik Pengolahan Data Pengujian Kuat Tekan Beton Normal (Fc'- SK 0\% + AT 0\%) Terhadap Fc' 25,00 MPa Menggunakan Benda Uji Selinder Ukuran 15x30 Cm. 
Tabel 4. Pengolahan Data Hasil Pengujian Kuat Tekan Beton Menggunakan Bahan Pengganti Serbuk Kaca Dan Abu Terbang (Fc'- SK 5\% + AT 5\%) Terhadap

Beton Normal Fc' 25,57 MPa Dengan Benda Uji Selinder Ukuran 15x30 Cm.

\begin{tabular}{|c|c|c|c|c|c|c|c|c|c|c|c|c|c|}
\hline \multirow{2}{*}{$\begin{array}{l}\text { Kode } \\
\text { Uji }\end{array}$} & \multirow{2}{*}{$\begin{array}{c}\text { Prosentase } \\
\text { Kandungan } \\
\text { SK + AT }\end{array}$} & \multirow{2}{*}{$\begin{array}{l}\text { Tgl. } \\
\text { Cor }\end{array}$} & \multirow{2}{*}{$\begin{array}{l}\text { Umur } \\
\text { ( Hari ) }\end{array}$} & \multirow{2}{*}{$\begin{array}{l}\mathrm{Tgl} \\
\mathrm{Uji}\end{array}$} & \multirow{2}{*}{$\begin{array}{l}\text { Slump } \\
(\mathrm{mm})\end{array}$} & \multirow{2}{*}{$\begin{array}{l}\text { Berat } \\
(\mathrm{Kg})\end{array}$} & \multicolumn{2}{|c|}{$\begin{array}{l}\text { Beban } \\
\text { Hancur }\end{array}$} & \multirow{2}{*}{$\begin{array}{l}\text { Luas } \\
\left(\mathrm{Cm}^{2}\right)\end{array}$} & \multirow{2}{*}{$\begin{array}{l}\text { Kuat } \\
\text { Tekan } \\
\text { ( MPa) }\end{array}$} & \multirow{2}{*}{$\begin{array}{l}\text { Konversi } \\
\text { Standar } \\
\text { Minimal }\end{array}$} & \multirow{2}{*}{$\begin{array}{l}\text { Standar } \\
\text { Deviasi } \\
\text { ( MPa ) }\end{array}$} & \multirow{2}{*}{$\begin{array}{c}\text { Pencapaian } \\
\text { Thd. Fc' 25,57 MPa } \\
\text { (\%) }\end{array}$} \\
\hline & & & & & & & $(\mathrm{kN})$ & $(\mathrm{Kg})$ & & & & & \\
\hline$F^{\prime}-3.1$ & \multirow{3}{*}{$5 \%+5 \%$} & $24 / 03 / 2018$ & 3 & $27 / 03 / 2018$ & 80 & 11,87 & 120 & 12000 & 176,63 & 6,79 & \multirow{3}{*}{11,50} & \multirow{3}{*}{0,57} & \multirow{3}{*}{-36} \\
\hline$F^{\prime}-3.2$ & & $24 / 03 / 2018$ & 3 & $27 / 03 / 2018$ & 80 & 12,06 & 140 & 14000 & 176,63 & 7,93 & & & \\
\hline$F c^{\prime}-3.3$ & & $24 / 03 / 2018$ & 3 & $27 / 03 / 2018$ & 80 & 11,92 & 130 & 13000 & 176,63 & 7,36 & & & \\
\hline \multicolumn{10}{|c|}{ Rata - rata } & 7,36 & & & \\
\hline $\mathrm{Fc}^{\prime}-14.4$ & \multirow{3}{*}{$5 \%+5 \%$} & $24 / 03 / 2018$ & 14 & 07/04/2018 & 80 & 12,28 & 325 & 32500 & 176,63 & 18,40 & \multirow{3}{*}{22,00} & \multirow{3}{*}{0,43} & \multirow{3}{*}{$-18,5$} \\
\hline $\mathrm{Fc}^{\prime}-14.5$ & & $24 / 03 / 2018$ & 14 & $07 / 04 / 2018$ & 80 & 12,12 & 310 & 31000 & 176,63 & 17,55 & & & \\
\hline $\mathrm{Fc}^{\prime}-14.6$ & & $24 / 03 / 2018$ & 14 & $07 / 04 / 2018$ & 80 & 12,20 & 315 & 31500 & 176,63 & 17,83 & & & \\
\hline \multicolumn{10}{|c|}{ Rata - rata } & 17,93 & & & \\
\hline$F c^{\prime}-28.7$ & \multirow{3}{*}{$5 \%+5 \%$} & $24 / 03 / 2018$ & 28 & $21 / 04 / 2018$ & 80 & 12,46 & 420 & 42000 & 176,63 & 23,78 & \multirow{3}{*}{25,57} & \multirow{3}{*}{0,49} & \multirow{3}{*}{$-8,10$} \\
\hline $\mathrm{Fc}^{\prime}-28.8$ & & $24 / 03 / 2018$ & 28 & $21 / 04 / 2018$ & 80 & 12,30 & 405 & 40500 & 176,63 & 22,93 & & & \\
\hline $\mathrm{Fc}^{\prime}-28.9$ & & $24 / 03 / 2018$ & 28 & $21 / 04 / 2018$ & 80 & 12,42 & 420 & 42000 & 176,63 & 23,78 & & & \\
\hline
\end{tabular}

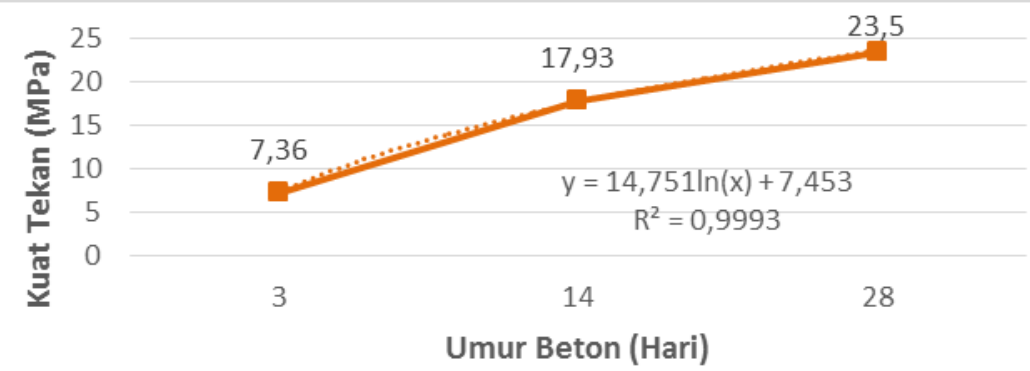

Gambar 4. Grafik Pengolahan Data Hasil Pengujian Kuat Tekan Beton Menggunakan Bahan Pengganti Serbuk Kaca Dan Abu Terbang (Fc'-SK 5\% + AT 5\%) Terhadap Beton Normal Fc' 25,57 MPa Dengan Benda Uji Selinder Ukuran 15x30 Cm.

Tabel 5. Pengolahan Data Hasil Pengujian Kuat Tekan Beton Menggunakan Bahan Pengganti Serbuk Kaca Dan Abu Terbang (Fc'- SK 10\% + AT 5\%) Terhadap Beton NormalFc' 25,57 MPa Dengan Benda Uji Selinder Ukuran 15x30 Cm.

\begin{tabular}{|c|c|c|c|c|c|c|c|c|c|c|c|c|c|}
\hline \multirow{2}{*}{$\begin{array}{l}\text { Kode } \\
\text { Uji }\end{array}$} & \multirow{2}{*}{$\begin{array}{c}\text { Prosentase } \\
\text { Kandungan } \\
\text { SK + AT }\end{array}$} & \multirow{2}{*}{$\begin{array}{l}\text { Tgl. } \\
\text { Cor }\end{array}$} & \multirow{2}{*}{$\begin{array}{l}\text { Umur } \\
\text { ( Hari ) }\end{array}$} & \multirow{2}{*}{$\begin{array}{l}\text { Tgl } \\
\text { Uji }\end{array}$} & \multirow{2}{*}{$\begin{array}{l}\text { Slump } \\
(\mathrm{mm})\end{array}$} & \multirow{2}{*}{$\begin{array}{l}\text { Berat } \\
(\mathrm{Kg})\end{array}$} & \multicolumn{2}{|c|}{$\begin{array}{l}\text { Beban } \\
\text { Hancur }\end{array}$} & \multirow{2}{*}{$\begin{array}{l}\text { Luas } \\
\left(\mathrm{Cm}^{2}\right)\end{array}$} & \multirow{2}{*}{$\begin{array}{l}\text { Kuat } \\
\text { Tekan } \\
\text { ( MPa ) }\end{array}$} & \multirow{2}{*}{$\begin{array}{l}\text { Konversi } \\
\text { Standar } \\
\text { Minimal }\end{array}$} & \multirow{2}{*}{$\begin{array}{l}\text { Standar } \\
\text { Deviasi } \\
\text { ( MPa ) }\end{array}$} & \multirow{2}{*}{$\begin{array}{c}\text { Pencapaian } \\
\text { Thd. F' } 25,57 \mathrm{MPa} \\
\text { (\%) }\end{array}$} \\
\hline & & & & & & & $(\mathrm{kN})$ & $(\mathrm{Kg})$ & & & & & \\
\hline $\mathrm{Fc}^{\prime}-3.1$ & \multirow{3}{*}{$10 \%+5 \%$} & 26/03/2018 & 3 & 29/03/2018 & 75 & 12,13 & 145 & 14500 & 176,63 & 8,21 & \multirow{3}{*}{11,50} & \multirow{3}{*}{0,71} & \multirow{3}{*}{$-29,39$} \\
\hline$F^{\prime}-3.2$ & & 26/03/2018 & 3 & 29/03/2018 & 75 & 12,07 & 130 & 13000 & 176,63 & 7,36 & & & \\
\hline $\mathrm{Fc}^{\prime}-3.3$ & & 26/03/2018 & 3 & 29/03/2018 & 75 & 12,22 & 155 & 15500 & 176,63 & 8,78 & & & \\
\hline \multicolumn{10}{|c|}{ Rata - rata } & 8,12 & & & \\
\hline$F^{\prime}-14.4$ & \multirow{3}{*}{$10 \%+5 \%$} & $26 / 03 / 2018$ & 14 & 09/04/2018 & 75 & 12,25 & 330 & 33000 & 176,63 & 18,68 & \multirow{3}{*}{22,00} & \multirow{3}{*}{0,57} & \multirow{3}{*}{$-12,50$} \\
\hline Fc'-14.5 & & 26/03/2018 & 14 & 09/04/2018 & 75 & 12,33 & 340 & 34000 & 176,63 & 19,25 & & & \\
\hline$F^{\prime}-14.6$ & & 26/03/2018 & 14 & 09/04/2018 & 75 & 12,38 & 350 & 35000 & 176,63 & 19,82 & & & \\
\hline \multicolumn{10}{|c|}{ Rata - rata } & 19,25 & & & \\
\hline$F^{\prime}-28.7$ & \multirow{3}{*}{$10 \%+5 \%$} & 26/03/2018 & 28 & 23/04/2018 & 75 & 12,52 & 440 & 44000 & 176,63 & 24,91 & \multirow{3}{*}{25,57} & \multirow{3}{*}{0,91} & \multirow{3}{*}{$-5,16$} \\
\hline$F^{\prime}-28.8$ & & 26/03/2018 & 28 & 23/04/2018 & 75 & 12,41 & 410 & 41000 & 176,63 & 23,21 & & & \\
\hline$F^{\prime}-28.9$ & & $26 / 03 / 2018$ & 28 & 23/04/2018 & 75 & 12,49 & 435 & 43500 & 176,63 & 24,63 & & & \\
\hline & & & & Rata - rata & & & & & & 24,25 & & & \\
\hline
\end{tabular}




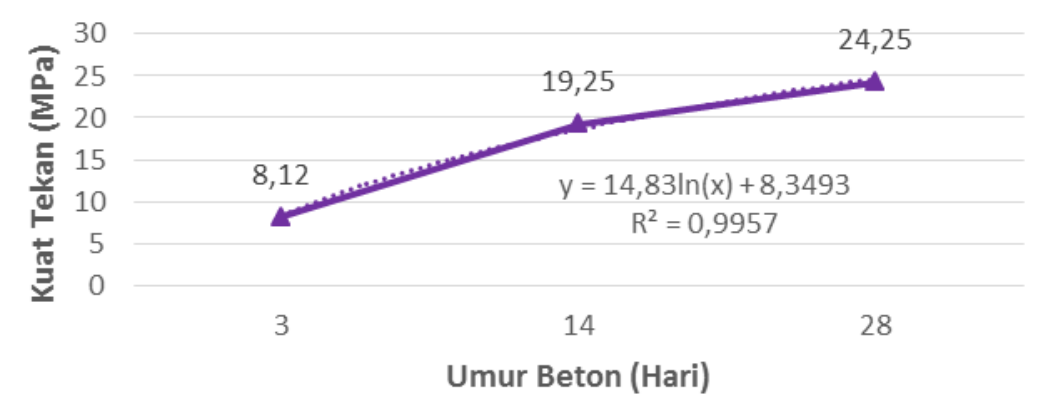

Gambar 5. Grafik Pengolahan Data Hasil Pengujian Kuat Tekan Beton Menggunakan Bahan Pengganti Serbuk Kaca Dan Abu Terbang (Fc'- SK 10\% + AT 5\%) Terhadap Beton Normal Fc' 25,57 MPa Dengan Benda Uji Selinder Ukuran 15x30 Cm

Tabel 6. Pengolahan Data Hasil Pengujian Kuat Tekan Beton Menggunakan Bahan Pengganti Serbuk Kaca Dan Abu Terbang (Fc'- SK 15\% + AT 5\%) Terhadap Beton Normal Fc' 25,57 MPa Dengan Benda Uji Selinder Ukuran 15x30 Cm.

\begin{tabular}{|c|c|c|c|c|c|c|c|c|c|c|c|c|c|}
\hline \multirow{2}{*}{$\begin{array}{l}\text { Kode } \\
\text { Uji }\end{array}$} & \multirow{2}{*}{$\begin{array}{c}\text { Prosentase } \\
\text { Kandungan } \\
\text { SK + AT }\end{array}$} & \multirow{2}{*}{$\begin{array}{l}\text { Tgl. } \\
\text { Cor }\end{array}$} & \multirow{2}{*}{$\begin{array}{l}\text { Umur } \\
\text { ( Hari ) }\end{array}$} & \multirow{2}{*}{$\begin{array}{l}\text { Tgl } \\
\text { Uji }\end{array}$} & \multirow{2}{*}{$\begin{array}{l}\text { Slump } \\
(\mathrm{mm})\end{array}$} & \multirow{2}{*}{$\begin{array}{l}\text { Berat } \\
(\mathrm{Kg})\end{array}$} & \multicolumn{2}{|c|}{$\begin{array}{l}\text { Beban } \\
\text { Hancur }\end{array}$} & \multirow{2}{*}{$\begin{array}{l}\text { Luas } \\
\left(\mathrm{Cm}^{2}\right)\end{array}$} & \multirow{2}{*}{$\begin{array}{l}\text { Kuat } \\
\text { Tekan } \\
\text { (MPa) }\end{array}$} & \multirow{2}{*}{$\begin{array}{c}\text { Konversi } \\
\text { Standar } \\
\text { Minimal }\end{array}$} & \multirow{2}{*}{$\begin{array}{l}\text { Standar } \\
\text { Deviasi } \\
\text { ( MPa ) }\end{array}$} & \multirow{2}{*}{$\begin{array}{c}\text { Pencapaian } \\
\text { Thd. Fc' 25,57 Mpa } \\
\text { (\%) }\end{array}$} \\
\hline & & & & & & & $(\mathrm{kN})$ & $(\mathrm{Kg})$ & & & & & \\
\hline $\mathrm{Fc}^{\prime}-3.1$ & \multirow{3}{*}{$15 \%+5 \%$} & $27 / 03 / 2018$ & 3 & $30 / 03 / 2018$ & 75 & 12,31 & 170 & 17000 & 176,63 & 9,62 & \multirow{3}{*}{11,50} & \multirow{3}{*}{0,71} & \multirow{3}{*}{$-22,09$} \\
\hline F' -3.2 & & $27 / 03 / 2018$ & 3 & $30 / 03 / 2018$ & 75 & 12,08 & 145 & 14500 & 176,63 & 8,21 & & & \\
\hline$F^{\prime}-3.3$ & & $27 / 03 / 2018$ & 3 & $30 / 03 / 2018$ & 75 & 12,28 & 160 & 16000 & 176,63 & 9,06 & & & \\
\hline & & & \multicolumn{3}{|c|}{ Rata - rata } & $y$ & $r$ & 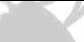 & 4 & 8,96 & & & \\
\hline Fc'-14.4 & \multirow{3}{*}{$15 \%+5 \%$} & $27 / 03 / 2018$ & 14 & $10 / 04 / 2018$ & 75 & 12,39 & 360 & 36000 & 176,63 & 20,38 & \multirow{3}{*}{22.00} & \multirow{3}{*}{0,86} & \multirow{3}{*}{$-6,50$} \\
\hline Fc'-14.5 & & $27 / 03 / 2018$ & 14 & $10 / 04 / 2018$ & 75 & 12,44 & 380 & 38000 & 176,63 & 21,51 & & & \\
\hline Fc'-14.6 & & $27 / 03 / 2018$ & 14 & $10 / 04 / 2018$ & 75 & 12,35 & 350 & 35000 & 176,63 & 19,82 & & & \\
\hline & & & \multicolumn{3}{|c|}{ Rata - rata } & \multicolumn{3}{|c|}{ 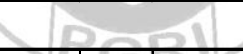 } & & 20,57 & \multirow{4}{*}{25,57} & & \\
\hline $\mathrm{Fc}^{\prime}-28.7$ & \multirow{3}{*}{$15 \%+5 \%$} & 27/03/2018 & 28 & $24 / 04 / 2018$ & 75 & 12,58 & 480 & 48000 & 176,63 & 27,18 & & \multirow{3}{*}{0,87} & \multirow{3}{*}{5,55} \\
\hline $\mathrm{Fc}^{\prime}-28.8$ & & $27 / 03 / 2018$ & 28 & $24 / 04 / 2018$ & 45 & 12,52 & 460 & 46000 & 176,63 & 26,04 & & & \\
\hline$F^{\prime}-28.9$ & & $27 / 03 / 2018$ & 28 & 24/04/2018 & 75 & 12,66 & 490 & 49000 & 176,63 & 27,74 & & & \\
\hline
\end{tabular}

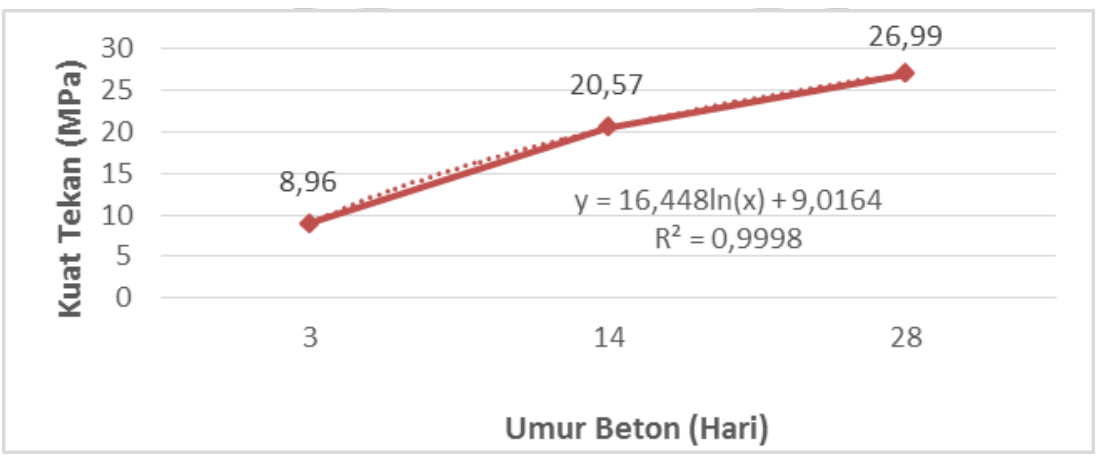

Gambar 6. Grafik Pengolahan Data Hasil Pengujian Kuat Tekan Beton Menggunakan Bahan Pengganti Serbuk Kaca Dan Abu Terbang (Fc'- SK 15\% + AT 5\%) Terhadap Beton Normal Fc' 25,57 MPa Dengan Benda Uji Selinder Ukuran $15 \times 30 \mathrm{Cm}$ 
Tabel 7. Pengolahan Data Hasil Pengujian Kuat Tekan Beton Menggunakan Bahan Pengganti Serbuk Kaca Dan Abu Terbang (Fc'- SK 20\% + AT 5\%) Terhadap

Beton Normal Fc' 25,57 MPa Dengan Benda Uji Selinder Ukuran 15x30 Cm.

\begin{tabular}{|c|c|c|c|c|c|c|c|c|c|c|c|c|c|}
\hline \multirow{2}{*}{$\begin{array}{c}\text { Kode } \\
\text { Uji }\end{array}$} & \multirow{2}{*}{$\begin{array}{c}\text { Prosentase } \\
\text { Kandungan } \\
\text { SK + AT }\end{array}$} & \multirow{2}{*}{$\begin{array}{l}\text { Tgl. } \\
\text { Cor }\end{array}$} & \multirow{2}{*}{$\begin{array}{l}\text { Umur } \\
\text { ( Hari }) \\
\end{array}$} & \multirow{2}{*}{$\begin{array}{l}\mathrm{Tgl} \\
\mathrm{Uji} \\
\end{array}$} & \multirow{2}{*}{$\begin{array}{l}\text { Slump } \\
(\mathrm{mm})\end{array}$} & \multirow{2}{*}{$\begin{array}{l}\text { Berat } \\
(\mathrm{Kg}) \\
\end{array}$} & \multicolumn{2}{|c|}{$\begin{array}{l}\text { Beban } \\
\text { Hancur }\end{array}$} & \multirow{2}{*}{$\begin{array}{l}\text { Luas } \\
\left(\mathrm{Cm}^{2}\right) \\
\end{array}$} & \multirow{2}{*}{$\begin{array}{l}\text { Kuat } \\
\text { Tekan } \\
\text { ( MPa ) }\end{array}$} & \multirow{2}{*}{$\begin{array}{c}\text { Konversi } \\
\text { Standar } \\
\text { Minimal }\end{array}$} & \multirow{2}{*}{$\begin{array}{l}\text { Standar } \\
\text { Deviasi } \\
\text { (MPa) }\end{array}$} & \multirow{2}{*}{$\begin{array}{c}\text { Pencapaian } \\
\text { Thd. Fc' 25,57 Mpa } \\
\quad(\%)\end{array}$} \\
\hline & & & & & & & $(\mathrm{kN})$ & $(\mathrm{Kg})$ & & & & & \\
\hline $\mathrm{Fc}^{\prime}-3.1$ & \multirow{3}{*}{$20 \%+5 \%$} & $28 / 03 / 2018$ & 3 & $31 / 03 / 2018$ & 70 & 12,29 & 165 & 16500 & 176,63 & 9,34 & \multirow{3}{*}{11,50} & \multirow{3}{*}{0,85} & \multirow{3}{*}{$-18,78$} \\
\hline$F c^{\prime}-3.2$ & & $28 / 03 / 2018$ & 3 & $31 / 03 / 2018$ & 70 & 12,16 & 150 & 15000 & 176,63 & 8,49 & & & \\
\hline$F^{\prime}-3.3$ & & $28 / 03 / 2018$ & 3 & $31 / 03 / 2018$ & 70 & 12,36 & 180 & 18000 & 176,63 & 10,19 & & & \\
\hline \multicolumn{10}{|c|}{ Rata - rata } & 9,34 & & & \\
\hline Fc'-14.4 & \multirow{3}{*}{$20 \%+5 \%$} & $28 / 03 / 2018$ & 14 & $11 / 04 / 2018$ & 70 & 12,80 & 410 & 41000 & 176,63 & 23,21 & \multirow{3}{*}{22,00} & \multirow{3}{*}{0,99} & \multirow{3}{*}{$-2,59$} \\
\hline Fc'-14.5 & & $28 / 03 / 2018$ & 14 & $11 / 04 / 2018$ & 70 & 12,44 & 375 & 37500 & 176,63 & 21,23 & & & \\
\hline Fc'-14.6 & & $28 / 03 / 2018$ & 14 & $11 / 04 / 2018$ & 70 & 12,61 & 395 & 39500 & 176,63 & 22,36 & & & \\
\hline \multicolumn{10}{|c|}{ Rata - rata } & 22,27 & & & \\
\hline$F_{c}-28.7$ & \multirow{3}{*}{$20 \%+5 \%$} & $28 / 03 / 2018$ & 28 & $25 / 04 / 2018$ & 70 & 13,05 & 480 & 48000 & 176,63 & 27,18 & \multirow{3}{*}{25,57} & \multirow{3}{*}{0,87} & \multirow{3}{*}{7,04} \\
\hline Fc'-28.8 & & $28 / 03 / 2018$ & 28 & $25 / 04 / 2018$ & 70 & 13,17 & 500 & 50000 & 176,63 & 28,31 & & & \\
\hline Fc'-28.9 & & $28 / 03 / 2018$ & 28 & $25 / 04 / 2018$ & 70 & 12,92 & 470 & 47000 & 176,63 & 26,61 & & & \\
\hline & & & & Rata - rata & 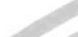 & 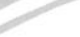 & & & & 27,37 & & & \\
\hline
\end{tabular}

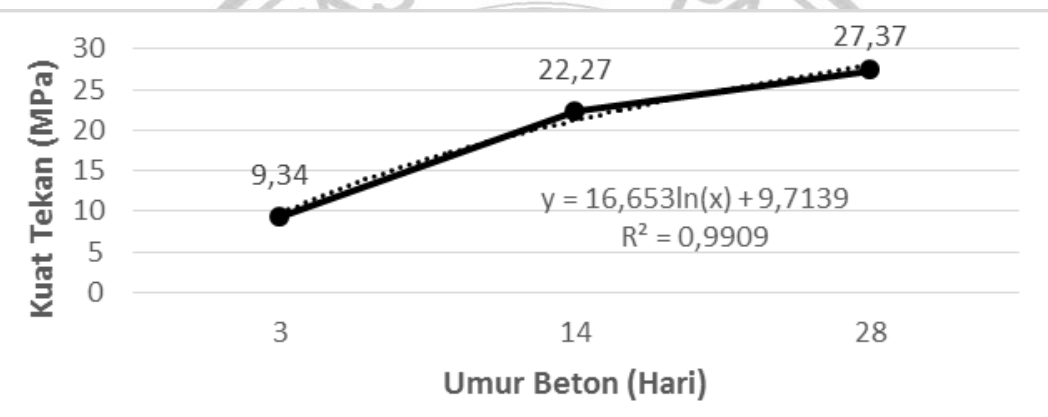

Gambar 7. Grafik Pengolahan Data Hasil Pengujian Kuat Tekan Beton Menggunakan Bahan Pengganti Serbuk Kaca Dan Abu Terbang (Fc'- SK 20\% + AT 5\%) Terhadap Beton Normal Fc' 25,57 MPa Dengan Benda Uji Selinder Ukuran 15x30 Cm.

Tabel 8. Pengolahan Data Hasil Pengujian Kuat Tekan Beton Menggunakan Bahan PenggantiSerbuk Kaca Dan Abu Terbang (Fc'- SK 25\% + AT 5\%) Terhadap

Beton Normal Fc' 25,57 MPa Dengan Benda Uji Selinder Ukuran $15 \times 30 \mathrm{Cm}$.

\begin{tabular}{|c|c|c|c|c|c|c|c|c|c|c|c|c|c|}
\hline \multirow{2}{*}{$\begin{array}{l}\text { Kode } \\
\text { Uji }\end{array}$} & \multirow{2}{*}{$\begin{array}{c}\text { Prosentase } \\
\text { Kandungan } \\
\text { SK + AT } \\
\end{array}$} & \multirow{2}{*}{$\begin{array}{l}\text { Tgl. } \\
\text { Cor }\end{array}$} & \multirow{2}{*}{$\begin{array}{l}\text { Umur } \\
\text { ( Hari ) } \\
\end{array}$} & \multirow{2}{*}{$\begin{array}{l}\mathrm{Tgl} \\
\mathrm{Uji} \\
\end{array}$} & \multirow{2}{*}{$\begin{array}{l}\text { Slump } \\
(\mathrm{mm}) \\
\end{array}$} & \multirow{2}{*}{$\begin{array}{l}\text { Berat } \\
(\mathrm{Kg}) \\
\end{array}$} & \multicolumn{2}{|c|}{$\begin{array}{l}\text { Beban } \\
\text { Hancur }\end{array}$} & \multirow{2}{*}{$\begin{array}{l}\text { Luas } \\
\left(\mathrm{Cm}^{2}\right) \\
\end{array}$} & \multirow{2}{*}{$\begin{array}{c}\text { Kuat } \\
\text { Tekan } \\
(\mathrm{MPa}) \\
\end{array}$} & \multirow{2}{*}{$\begin{array}{l}\text { Konvrsi } \\
\text { Standar } \\
\text { Minimal }\end{array}$} & \multirow{2}{*}{$\begin{array}{l}\text { Standar } \\
\text { Deviasi } \\
\text { (MPa) }\end{array}$} & \multirow{2}{*}{$\begin{array}{c}\text { Pencapaian } \\
\text { Thd. Fc' 25,57 Mpa } \\
(\%)\end{array}$} \\
\hline & & & & & & & $(\mathrm{kN})$ & $(\mathrm{Kg})$ & & & & & \\
\hline $\mathrm{Fc}^{\prime}-3.1$ & \multirow{3}{*}{$25 \%+5 \%$} & $31 / 03 / 2018$ & 3 & $03 / 04 / 2018$ & 70 & 12,35 & 180 & 18000 & 176,63 & 10,19 & \multirow{3}{*}{11,50} & \multirow{3}{*}{1,13} & \multirow{3}{*}{$-11,39$} \\
\hline $\mathrm{Fc}^{\prime}-3.2$ & & $31 / 03 / 2018$ & 3 & 03/04/2018 & 70 & 12,20 & 160 & 16000 & 176,63 & 9,06 & & & \\
\hline $\mathrm{Fc}^{\prime}-3.3$ & & $31 / 03 / 2018$ & 3 & 03/04/2018 & 70 & 12,42 & 200 & 20000 & 176,63 & 11,32 & & & \\
\hline \multicolumn{10}{|c|}{ Rata - rata } & 10,19 & & & \\
\hline Fc'-14.4 & \multirow{3}{*}{$25 \%+5 \%$} & $31 / 03 / 2018$ & 14 & 14/04/2018 & 70 & 13,07 & 420 & 42000 & 176,63 & 23,78 & \multirow{3}{*}{22,00} & \multirow{3}{*}{0,65} & \multirow{3}{*}{$-4,68$} \\
\hline Fc'-14.5 & & $31 / 03 / 2018$ & 14 & 14/04/2018 & 70 & 12,71 & 400 & 40000 & 176,63 & 22,65 & & & \\
\hline Fc'-14.6 & & $31 / 03 / 2018$ & 14 & $14 / 04 / 2018$ & 70 & 12,55 & 400 & 40000 & 176,63 & 22,65 & & & \\
\hline \multicolumn{10}{|c|}{ Rata - rata } & 23,03 & & & \\
\hline Fc'-28.7 & \multirow{3}{*}{$25 \%+5 \%$} & $31 / 03 / 2018$ & 28 & $28 / 04 / 2018$ & 70 & 13,10 & 475 & 47500 & 176,63 & 26,89 & \multirow{3}{*}{25,57} & \multirow{3}{*}{0,99} & \multirow{3}{*}{8,84} \\
\hline $\mathrm{Fc}^{\prime}-28.8$ & & $31 / 03 / 2018$ & 28 & $28 / 04 / 2018$ & 70 & 13,33 & 510 & 51000 & 176,63 & 28,87 & & & \\
\hline $\mathrm{Fc}^{\prime}-28.9$ & & $31 / 03 / 2018$ & 28 & $28 / 04 / 2018$ & 70 & 13,28 & 490 & 49000 & 176,63 & 27,74 & & & \\
\hline
\end{tabular}




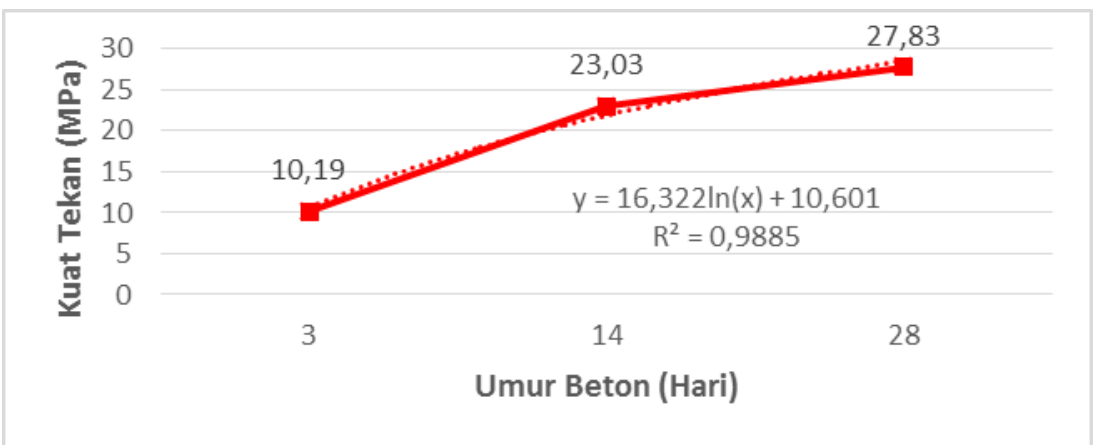

Gambar 8. Grafik Pengolahan Data Hasil Pengujian Kuat Tekan Beton Menggunakan Bahan Pengganti Serbuk Kaca Dan Abu Terbang (Fc'- SK 25\% + AT 5\%) Terhadap Beton Normal Fc' 25,57 MPa Dengan Benda Uji Selinder Ukuran 15x30 Cm.

\section{KESIMPULAN}

Berdasarkan hasil pemeriksaan dan penelitian yang telah dilakukan serta penjelasanpenjelasan dibab-bab sebelumnya maka dapat disimpulkan, yaitu:

1. Rancangan proporsi campuran beton dengan metode SNI-03-2834-2000 tercapai, karena kuat tekan rata-rata beton normal yang didapat dari hasil kajian laboratorium pada target umur 28 hari mencapai hasil yang direncanakan yaitu sebesar Fc' 25,57 MPa dan mengalami peningkatan kekuatan sebesar 2,28\% terhadap kuat tekan beton rencana yaitu $\mathrm{Fc}^{\prime}$ 25,00 MPa.

2. Pemanfaatan serbuk kaca dan abu terbang dapat memperbaiki sifat-sifat beton yaitu terhadap kuat tekannya, hal ini ditunjukkan dengan adanya peningkatan penambahan kandungan volume fraksi serbuk kaca dan abu terbang pada kapasitas kekuatan tekan hancur beton terhadap kuat tekan beton normal.

3. Semakin bertambahnya kandungan volume fraksi serbuk kaca dan abu terbang dalam adukan beton, nilai slump akan menurun. Hal ini disebabkan karena serbuk kaca sebagai subtitusi pasir dan abu terbang sebagai subtitusi semen dapat mencegah pemisahan antara butiran agregat dan mortar semen sehingga adukan menjadi lebih solid dan padat.

4. Dengan demikian dari hasil pengujian yang telah dilakukan bahwa pada penambahan campuran volume fraksi serbuk kaca dan abu terbang sebesar (Fc'- SK 25\% + AT $5 \%$ ) pada umur 7, 14 dan 28 hari nilai kekuatan hancur tekannya lebih tinggi dibandingkan dengan atau tanpa penambahan campuran volume fraksi serbuk kaca dan abu terbang sebesar (Fc'- SK 5\%, 10\%, 15\% dan 20\% + AT 5\%).

5. Dari hasil penelitian analisa pengaruh serbuk kaca dan abu terbang sebagai bahan pengganti alternatif terhadap kuat tekan beton diperoleh komposisi campuran yang optimal yaitu (Fc'- SK 15\% + AT 5\%) karena pada umur 28 hari nilai kuat tekan beton rata-ratanya sebesar $26,99 \mathrm{MPa}$ dengan pencapaian peningkatan kekuatan beton normal sebesar 5,55\%. 


\section{DAFTAR PUSTAKA}

Mulyono, Tri (2003). “Teknologi Beton”. Jakarta: Andi Yogyakarta.

Nawy, Edward G. (2010). “Beton Bertulang”. Bandung: Refika Aditama.

Setiawan, Agus (2016). "Perencanaan Struktur Beton Bertulang Berdasarkan SNI 2847: 2013”. Jakarta: Erlangga.

Standar Nasional Indonesia. "Metode Pengujian Tentang Analisis Saringan Agregat Halus dan Kasar”. Indonesia: SNI-03-1968-1990.

Standar Nasional Indonesia. “Ordinai Portland Cement”. Indonesia: SNI-15-3550-2004.

Standar Nasional Indonesia. "Standar Portland Cement”. Indonesia: SNI-15-3550-2000.

Standar Nasional Indonesia. "Tata Cara Pembuatan Rencana Campuran Beton Normal”. Indonesia: SNI-03-2834-2000.

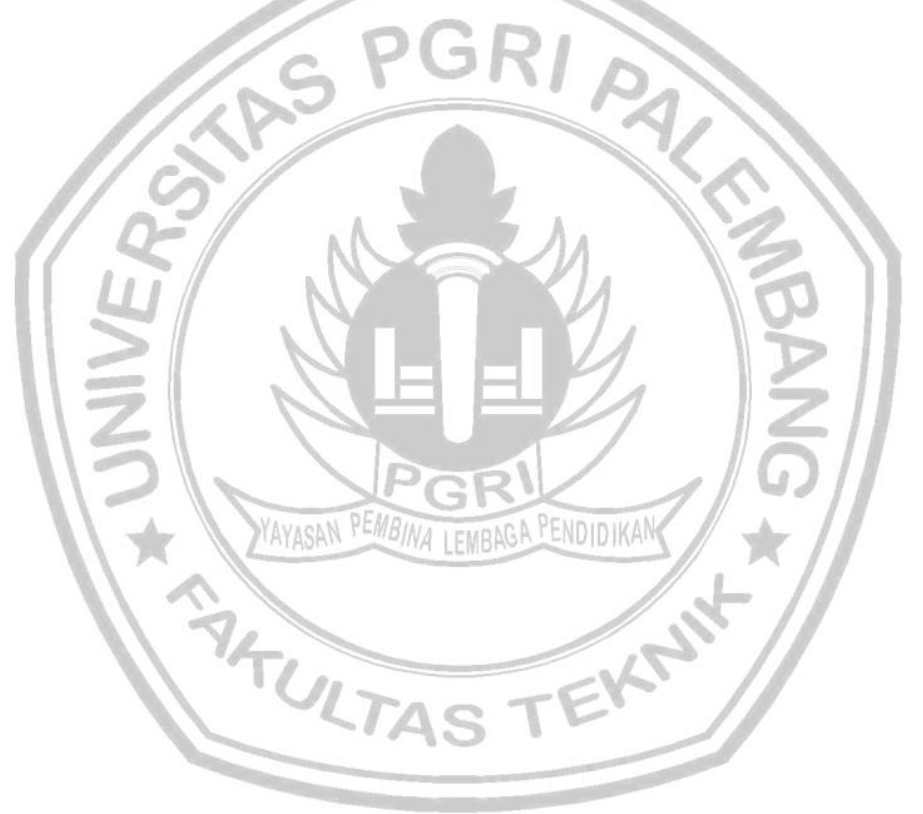

